\title{
Investigating periphyton response to changing phosphorus concentrations in UK rivers using within-river flumes
}

\author{
Michael J Bowes, Katja Lehmann, Helen Jarvie and Andrew C Singer
}

Centre for Ecology and Hydrology, Wallingford, UK

E-mail:mibo@ceh.ac.uk

\begin{abstract}
The excessive growth of benthic algal biofilms in UK rivers is a widespread problem, resulting in loss of plant communities and wider ecological damage. Elevated nutrient concentrations (particularly phosphorus) are often implicated, as P is usually considered the limiting nutrient in most rivers. Phosphorus loadings to rivers in the UK have rapidly decreased in the last decade, due to improvements in sewage treatment and changes to agricultural practises. However, in many cases, these improvements in water quality have not resulted in a reduction in nuisance algal growth. It is therefore vital that catchment managers know what phosphorus concentrations need to be achieved, in order to meet the UK's obligations to attain good ecological status, under the EU's Water Framework Directive. This study has developed a novel methodology, using withinriver mesocosms, which allows P concentrations of river water to be either increased or decreased, and the effect on biofilm accrual rate is quantified. These experiments identify the phosphorus concentrations at which algae becomes P-limited, which can be used to determine knowledge-based $\mathrm{P}$ targets for rivers. The ability to reduce $\mathrm{P}$ concentrations in river water enables algae-nutrient limitation to be studied in nutrient-enriched rivers for the first time.
\end{abstract}

\section{Introduction}

Much effort is currently being focused on reducing phosphorus $(\mathrm{P})$ concentrations in nutrient-impacted UK freshwaters, to improve environmental status and reduce the risk of eutrophication. Initiatives such as the Urban Wastewater Treatment Directive (EEC, 1991) have been successful in producing significant reductions in $\mathrm{P}$ concentrations in the largely urbanised lowland catchments across the European Union, primarily as a result of introducing tertiary water treatment (P stripping) at major sewage treatment works (STW) (Bowes et al., 2005; Bowes et al., 2009; Foy, 2007). However, these step-changes in phosphorus loading often have no effect on algal growth rate or community structure (Kelly and Wilson, 2004), suggesting that $\mathrm{P}$ concentrations are still not limiting (or colimiting) algal growth in many of these rivers. It is vital that catchment managers and policy makers are provided with key information before instigating nutrient reduction strategies for a particular river. In particular, they need to know which plant nutrient (if any) is actually controlling algal biomass and how much this nutrient needs to be reduced by, to produce an 'acceptable' algal growth rate.

Traditional methodologies for investigating nutrient limitation of algae, such as nutrient-diffusing periphytometers (Matlock et al., 1998), nutrient diffusing substrata (Scrimgeour and Chambers, 1997; Tank and Dodds, 2003) and river fertilisation experiments (Harvey et al., 1998; Sabater et al., 2005) are only able to increase nutrient concentrations, and so can only be used in relatively pristine environments where nutrients are not in excess. These methodologies are of little use in the highly nutrientenriched rivers of lowland Britain, where phosphate and nitrate concentrations have commonly been elevated by high population densities and intensive farming practises.

A new methodology was developed by Bowes et al.
(2007) to enable periphyton limitation to be investigated in a phosphorus-enriched river (the River Frome, Dorset, UK). For the first time, it allowed the phosphorus concentrations of river water to be simultaneously increased and decreased (by chemical precipitation), using a set of streamside throughflow flumes. The periphyton accumulation rates in each flume resulting from this range of $\mathrm{P}$ concentrations were then estimated by chlorophyll- $a$ analysis. This work identified a phosphorus limiting concentration for the River Frome of ca. $90 \mu \mathrm{g} \mathrm{SRP} \mathrm{l}^{-1}$ (i.e. the accrual rate of periphyton began to be reduced / limited when the P concentration fell below $90 \mu \mathrm{g}^{-1}$ ), which gave a maximum soluble reactive phosphorus (SRP) concentration target for catchment managers to aim for during the summer algal growing season (Bowes et al., 2007).

This paper aims to develop a portable, within-stream flume mesocosm system that will allow the phosphorusstripping methodology of Bowes et al. (2007) to be applied to the upper River Kennet, Wiltshire, UK. This methodology will be used to investigate how changing phosphorus concentrations affect periphyton accrual rates, to determine if intermittent failures of the Marlborough STW are responsible for the periphyton-dominated ecology, and to determine a knowledge-based target phosphorus concentration for the upper River Kennet.

\footnotetext{
Study site

The River Kennet is one of the major tributaries of the River Thames, with a total catchment area of $c a .1200 \mathrm{~km}^{2}$. It rises north of the village of Avebury in Wiltshire, and flows in an easterly direction to discharge into the River Thames at the town of Reading, ca. $30 \mathrm{~km}$ west of London (Figure 1). The land use of the upper River Kennet is predominantly grassland and arable, with the only significant town being Marlborough, with a population of $c a .12000$ people. The
} 


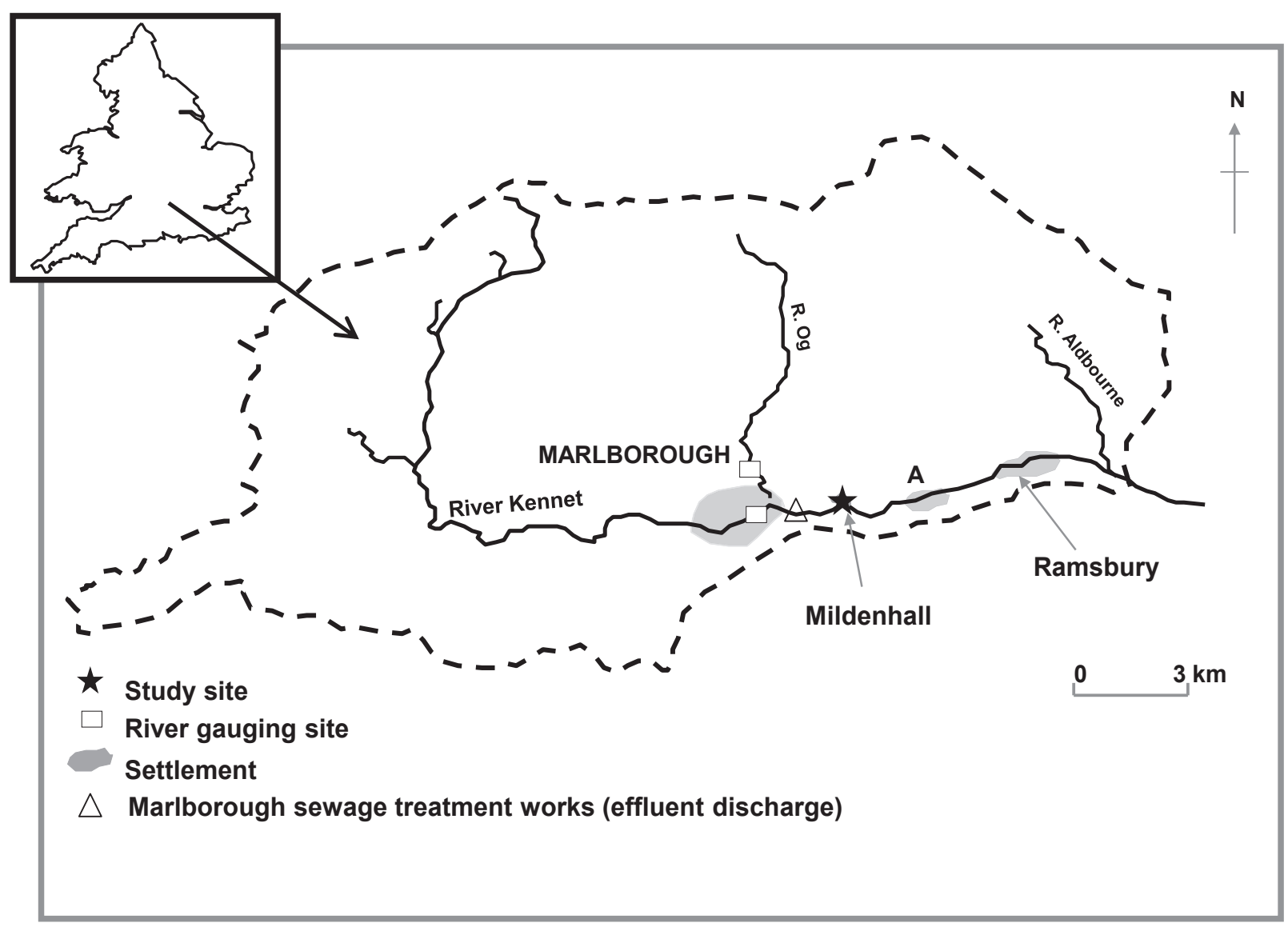

Figure 1 Map of the upper River Kennet, Wiltshire, showing location of study area and river gauging stations.

catchment geology is predominantly Cretaceous Chalk. A more detailed description of the River Kennet catchment can be found elsewhere (Neal et al., 2008; Wade et al., 2002).

The upper River Kennet has suffered major ecological problems since at least the 1990s (Wright et al., 2002), with large stretches of the river being dominated by periphyton, resulting in an absence of macrophytes (Periphyton is a complex mixture of algae, cyanobacteria, hetrotrophic microbes and associated detritus). Such symptoms are usually attributed to eutrophication; the anthropogenic enrichment of water bodies with plant nutrients, resulting in excessive periphyton growth rates which can smother and shade out higher plants (O'Hare et al., 2010; Hilton et al., 2006). Phosphorus has traditionally been seen as the limiting nutrient controlling biomass production in rivers (Mainstone and Parr, 2002). Therefore, to combat excessive periphyton growth in the River Kennet, great effort has been focused on reducing riverine phosphorus concentrations by introducing phosphorus stripping at the STW serving the town of Marlborough in 1997. This was extremely successful in improving the water quality of the River Kennet, resulting in a $70 \%$ reduction in phosphorus concentration from $c a .600 \mu \mathrm{g} \mathrm{l}^{-1}$ to $c a .100 \mu \mathrm{g} \mathrm{l}^{-1}$ soluble reactive phosphorus (SRP) (Jarvie et al., 2002). SRP is essentially a measure of bioavailable phosphate in rivers (Nurnberg and Peters, 1984). Studies in 2002 indicated that despite the major improvement in water quality, the ecological health of the river seemed to have declined, and showed that regular epiphyte blooms appeared to coincide with peaks in phosphorus concentrations (despite these peaks being lower than the average phosphorus concentration prior to P stripping), implying that the aquatic ecosystem had become 'sensitised' (Jarvie, Neal and Williams, 2004; Neal et al., 2008). Throughout the mid to late 2000s, the Marlborough STW underwent further improvements (with an average annual phosphorus consent limit in the final effluent of 1 $\mathrm{mgl}^{-1}$ ), resulting in further improvements in water quality and reductions in annual average SRP concentration to $84 \mu^{-1}$ in the period $2004-2005$ (Neal et al., 2008). However, much of the upper River Kennet still has sparse macrophyte standing crop with the ecology dominated by periphyton, and anecdotal evidence suggests that the environmental health of the river has declined further.

This study sought to examine how the biology of the upper River Kennet could be 'improved', and the ecology encouraged towards being macrophyte-dominated, rather than periphyton-dominated. This study aimed to determine if catchment managers should be trying to control nuisance algal growth by further reducing the average phosphorus concentration, or by controlling intermittent spikes in $\mathrm{P}$ concentration. To answer this, catchment managers need to know if the phosphorus concentration is actually limiting periphyton growth. This study aimed to establish if the periphyton were phosphorus-limited, and if not (i.e. phosphorus is in excess), then how much does the $\mathrm{P}$ concentration need to be reduced by to begin to limit the periphyton growth rate.

This study took place at the village of Mildenhall (grid reference SU212693), approximately $2 \mathrm{~km}$ downstream of the town of Marlborough and its sewage treatment works. This section of the river was particularly badly affected by excessive benthic algal growth, and the majority of the river bed was covered in a thick layer of periphyton throughout the spring to autumn period in both 2008 and 2009. The study reach had very low macrophyte biomass (mainly Callitriche platycarpa) and an almost complete absence of Ranunculus; a key macrophyte for chalk rivers. The river width at the study site was $9 \mathrm{~m}$, and average depth was $0.5 \mathrm{~m}$. The mean annual river flow at the site (from 1972 to 2005) was $1.2 \mathrm{~m}^{3} \mathrm{~s}^{-1}$ (Marsh and Hannaford, 2008). 


\section{Methods}

\section{Within-river flume design}

The flume mesocosm design used during these experiments is shown in Figure 2. Each plastic flume was $5 \mathrm{~m}$ long and $0.3 \mathrm{~m}$ wide, with gates at the upstream end, to control the flow rate of river water entering the flume. Floats were attached along the sides of each set of three flumes, to maintain them at a constant water depth of $4 \mathrm{~cm}$, irrespective of the changing water depth in the river. The flumes were secured in place in the river by sliding them over metal poles that were driven into the river bed. Each flume had a $3 \mathrm{~cm}$ deep and $15 \mathrm{~cm}$ long sump two thirds of the way down the flume, to collect chemical precipitate (from phosphorus reduction treatments) and any river debris that entered the flume, preventing it from entering the lower section of the flume.

\section{Details of flume experiment}

Six flumes were deployed in the River Kennet at Mildenhall, in a river reach with no shading from riparian vegetation and relatively uniform flow. The apertures of the gates at the upstream end of each flume were adjusted until a water velocity of $0.12 \mathrm{~m} \mathrm{~s}^{-1}$ (measured using a Valeport 801 electromagnetic flow meter) was recorded in the middle section of each flume.

The experiment commenced on the $25^{\text {th }}$ May, 2009. Treatments were randomly assigned to each flume, to produce simultaneously a range of phosphorus concentrations,

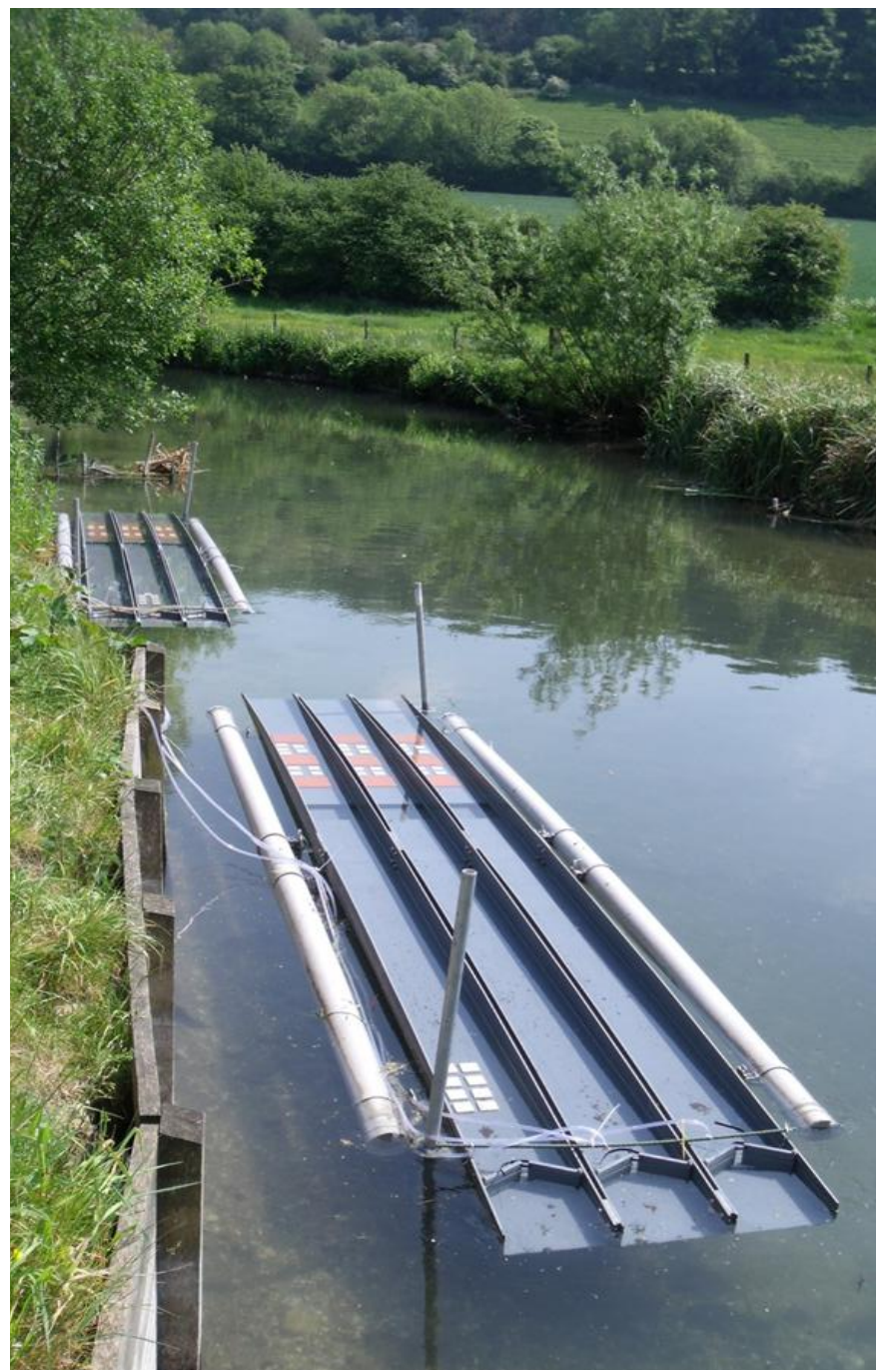

Figure 2 Photograph of flume experiment at the Mildenhall study site, viewed in a downstream direction. Note the lack of macrophytes within this stretch of the river.
Table 1 Mean nutrient concentrations in flumes during experiment

\begin{tabular}{lc}
\hline Treatment & SRP concentration $\left(\mu g l^{-1}\right)$ \\
\hline P addition & 170 \\
P addition & 102 \\
None (Control) & 60 \\
None (Control) & 55 \\
Fe addition & 39 \\
Fe addition & 27 \\
\hline
\end{tabular}

spanning the ambient river concentration at the time of the experiment (Table 1). Two of the flumes received a continuous addition of concentrated potassium dihydrogen orthophosphate solution into the upper section of the flumes, to produce an approximate doubling and tripling of the average ambient phosphorus concentration (which was $55 \mu \mathrm{g} \mathrm{l}^{-1}$ at the start of the experiment). Another two flumes received continuous additions of a concentrated iron (II) sulphate solution. This added iron reacted with the soluble, bioavailable phosphate in the incoming river water, forming a non-bioavailable precipitate, and thereby reducing the SRP concentration within the flume. The iron addition rates were adjusted until the SRP concentrations in the incoming river water (measured in the lower part of the flumes, where the tile substrates were to be positioned) were reduced by $c a .25$ and $50 \%$. These phosphorus and iron additions were delivered to the upstream end of the flumes (to allow the chemical treatments to fully mix with the incoming river water and to allow time for the iron - phosphorus precipitation reaction to occur) from stock bottles on the river bank via pipes, using a multi-channel peristaltic pump. The remaining two flumes received no chemical additions, and contained unmodified river water. These two channels acted as experimental controls.

When the required SRP concentrations were achieved, three unglazed ceramic tiles were placed in the lower section of each flume. The SRP concentrations were monitored approximately four times per day. Water samples $(60 \mathrm{ml})$ were taken from above the middle of the three ceramic tiles and immediately filtered through a 0.45 $\mu \mathrm{m}$ cellulose nitrate membrane filter and analysed for SRP concentration (within 10 minutes) using a field autosampler / analyser (Micromac C, Systea Analytical Technologies, Anagni, Italy). Parallel investigations during this study confirmed that filtering the iron-dosed river water stopped the phosphorus stripping reaction, thereby allowing the true SRP concentration overlying the periphyton to be quantified. After nine days ( $2^{\text {nd }}$ June, 2009), a thick periphyton biofilm had developed on some of the tiles, and sloughing appeared to be imminent. The tiles and associated periphyton were carefully removed, placed into sealed plastic bags, and stored in the dark at $4^{\circ} \mathrm{C}$, and returned to the laboratory for chlorophyll- $a$ analysis.

\section{Chlorophyll analysis}

The periphyton biomass on each tile was estimated by chlorophyll- $a$ analysis. The periphyton was washed and scraped from each tile, using $500 \mathrm{ml}$ deionised water. The resulting suspension was homogenised, a $20 \mathrm{ml}$ sub- sample taken and filtered through a GF/C grade filter paper (Whatman International Ltd., Maidstone, UK). The amount of chlorophyll- $a$ in each subsample was quantified spectrophotometrically following overnight extraction in $90 \%$ acetone (Marker et al., 1980).

\section{River Kennet phosphorus monitoring}

Water samples were collected from the River Kennet at Mildenhall at fortnightly intervals, from April 2008 to 
August 2009, so that the nutrient status of the river during the period of flume experiments could be set into context of the annual nutrient cycle. Aliquots of these samples were immediately filtered through a $0.45 \mu \mathrm{m}$ cellulose nitrate filter membrane (Whatman International Ltd., Maidstone, UK). The unfiltered samples were analysed for total phosphorus (TP) by persulphate digestion, and were then quantified by colorimetry (Eisenreich, Bannerman and Armstrong, 1975). The filtered water samples were also analysed for SRP, by reacting with molybdate and subsequent quantification using spectrophotometry (Murphy and Riley, 1962; Truesdale and Smith, 1975).

\section{Results}

\section{Flume phosphorus concentrations}

The concentrations of SRP observed in each flume, resulting from the addition of either phosphorus or iron solutions, are shown in Figure 3. The river water SRP concentration (as observed in the control treatment flumes) was relatively constant throughout the period of the experiment, with an average of $58 \mu \mathrm{g} \mathrm{l}^{-1}$ and ranging from 48 to $72 \mu \mathrm{g} \mathrm{l}^{-1} \mathrm{SRP}$. The $\mathrm{P}$ and iron additions produced a wide range of SRP concentrations simultaneously within the flumes, ranging from a maximum concentration of $237 \mu \mathrm{g} \mathrm{l}^{-1}$ to a minimum of $10 \mu \mathrm{g} \mathrm{l}^{-1}$. The iron dosing methodology of Bowes et al., (2007) was successful in reducing mean SRP concentrations of the incoming river water from $58 \mu \mathrm{g} \mathrm{l}^{-1}$ to 39 and $27 \mu \mathrm{g}$ $1^{-1}$ (Figure 3; Table 1), which was equivalent to a reduction of 32 and $53 \%$ respectively. The two flumes receiving phosphorus additions had concentrations ranging from 80 to $127 \mu \mathrm{g} \mathrm{l}^{-1}$ (mean concentration $=102 \mu \mathrm{g} \mathrm{l}^{-1}$ ) and 100 to 237 $\mu \mathrm{g} \mathrm{l}^{-1}$ (mean concentration $=170 \mu \mathrm{g} \mathrm{l}^{-1}$ ), which is equivalent to percentage increases of 176 and $293 \%$ respectively. The nitrate concentration in the River Kennet during this period was $7.8 \mathrm{mg} \mathrm{l}^{-1} \mathrm{NO}_{3}-\mathrm{N}$, which meant that $\mathrm{N}: \mathrm{P}$ molar ratios ranged from 102:1 (for the flume with the highest mean P concentration of $170 \mu \mathrm{g} \mathrm{l}^{-1}$ ) to $639: 1 \mathrm{~N}: \mathrm{P}$ (for the iron addition flume with the lowest SRP concentration of $27 \mu \mathrm{gl}^{-1}$ ). These ratios are much higher than the 16:1 N:P Redfield ratio (Redfield, 1958) suggesting that phosphorus is more likely to be limiting periphyton growth than nitrate.

\section{Periphyton accrual rate}

The quantity of periphyton that had colonised each tile was estimated by chlorophyll-a analysis (Figure 4). There was no significant difference between the periphyton accrual rate in the control and $\mathrm{P}$ addition flumes, with mean chlorophyll- $a$ concentrations of between 12.7 and $13.7 \mu \mathrm{g} \mathrm{cm}^{-2}$. This observation shows that the SRP concentration in the River Kennet at the time of the experiment was high enough to sustain the maximum periphyton growth rate, and implies that $\mathrm{P}$ is not limiting biofilm growth (i.e. SRP concentration was in excess). However, when the SRP concentration of the river was decreased below the 55-60 $\mu \mathrm{g} \mathrm{l}^{-1}$ ambient concentration, the periphyton accrual rate decreased significantly, with the concentration of chlorophyll-a reduced by a third when the mean SRP concentration was reduced to $27 \mu \mathrm{g} \mathrm{l}^{-1}$. Therefore periphyton growth was clearly phosphorus limited when SRP concentration decreased to a mean concentration of $37 \mu \mathrm{g} \mathrm{l}^{-1}$.

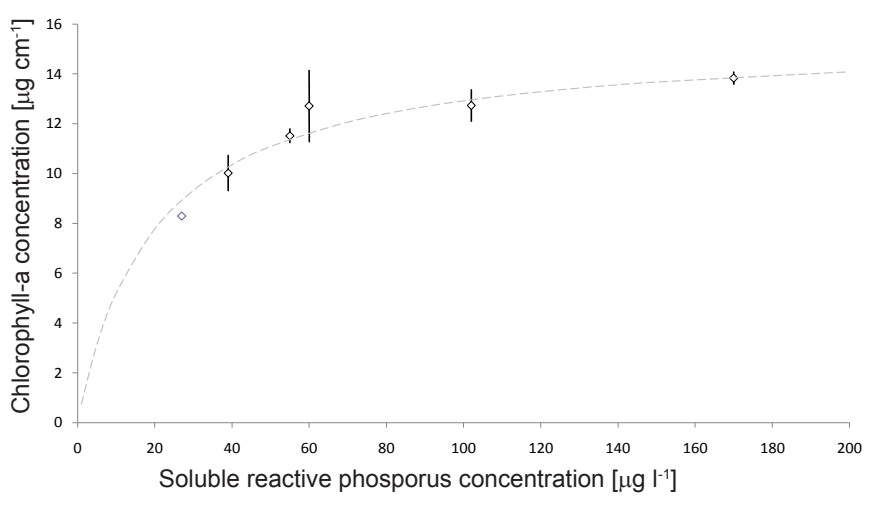

Figure 4 Chlorophyll-a concentrations on tile substrates at end of experiment. Data points are mean values \pm 1 standard error $(n=3)$. The dashed line represents the best fit of the data to Michaelis-Menton hyperbolic regression analysis (Dawes, 1972)

\section{River phosphorus concentrations}

The total $\mathrm{P}$ and soluble reactive $\mathrm{P}$ concentrations in the upper River Kennet at Mildenhall between April 2008 and August 2009 are shown in Figure 5. The average SRP concentration throughout this monitoring period was $66 \mu \mathrm{g} \mathrm{l}^{-1}$, which is around the Environment Agency's proposed phosphorus

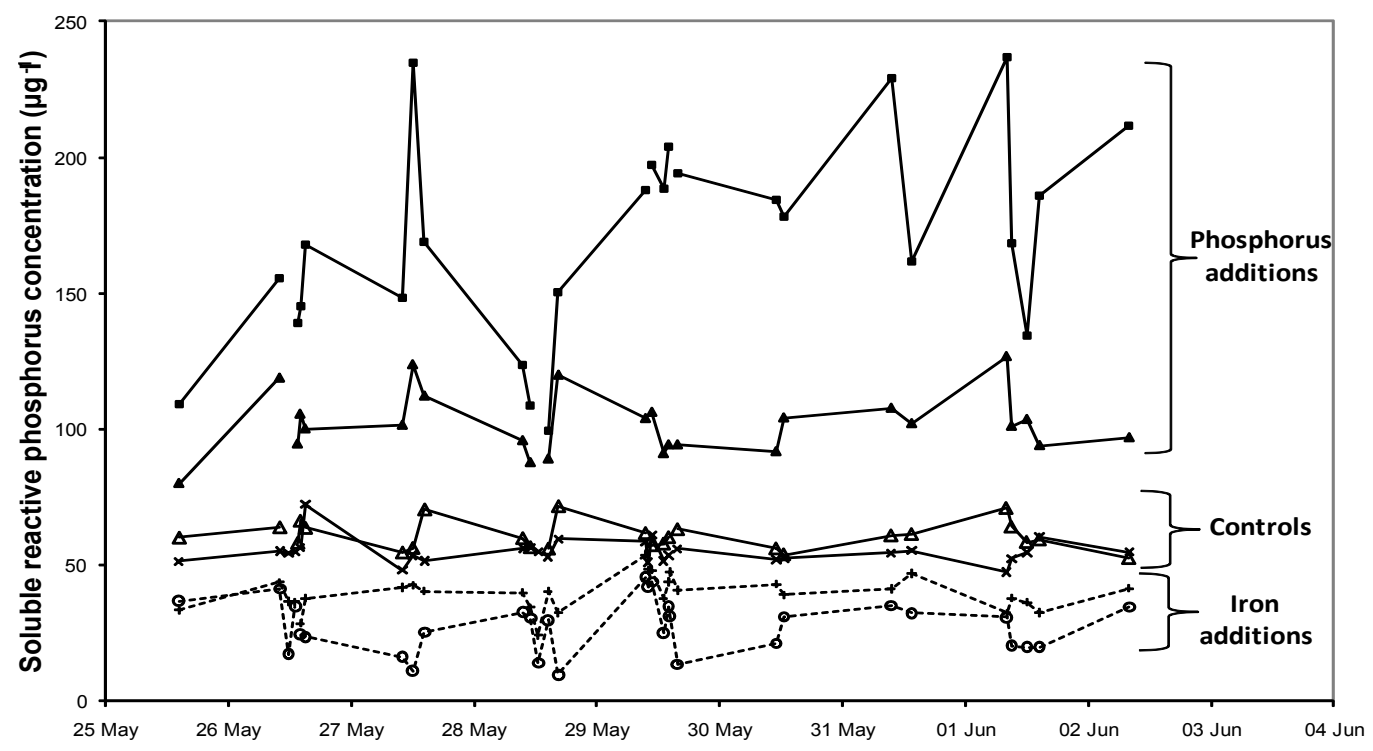

Figure 3 Soluble reactive phosphorus (SRP) concentrations in flumes during experiment. Solid lines and symbols = flumes receiving SRP additions. Solid lines with unfilled symbols $=$ control flumes. Dashed lines and unfilled symbols $=$ flumes with SRP stripping by iron addition. 


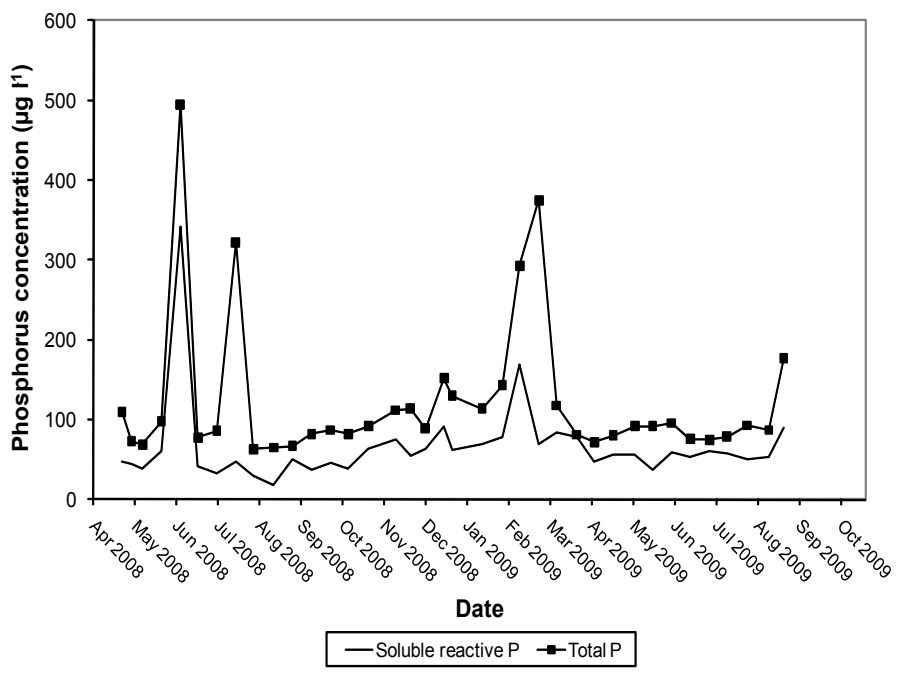

Figure 5 Phosphorus concentrations in upper River Kennet at Mildenhall (April 2008 to August 2009).

target for chalk rivers, which is an annual average of $60 \mu \mathrm{gl}^{-1}$. The peaks in phosphorus concentration observed by Jarvie et al. (2004) at this study site still occur, but are much less frequent than in 2002.

\section{Discussion}

\section{Effect of changing phosphorus concentration on periphyton accrual rate}

The SRP concentration in the river during this experiment (ca. $58 \mu \mathrm{g} \mathrm{l}^{-1}$ ) is at the breakpoint in the SRP / chlorophyll-a relationship (Figure 4), indicating that the river is at or near the phosphorus limiting concentration for periphyton growth (i.e. increases in phosphorus concentration do not increase periphyton growth rate, but decreases in SRP concentration lead to decreased periphyton growth). When a similar P stripping methodology was applied to the River Frome in Dorset, UK (Bowes et al., 2007), it also showed that the river was approximately at the $\mathrm{P}$ limiting concentration, although the breakpoint in the SRP / chlorophyll-a concentration relationship occurred at $c a .90 \mu \mathrm{g} \mathrm{l}^{-1}$, rather than $c a .58 \mu \mathrm{gl}^{-1}$. Another possible explanation of this pattern in the P concentration / chlorophyll relationship is that the addition of iron solution is in some way inhibiting periphyton growth. During the River Frome study, nutrient diffusing periphytometers were used in the iron-dosed flumes to resupply phosphorus, and this produced a significant increase in periphyton growth (Bowes et al., 2007). This strongly indicated that the reduced biofilm growth in the iron-dosed flumes was due to a lack of bioavailable phosphorus, rather than inhibition due to the presence of iron.

\section{Implications for catchment management}

These two flume experiments on these two chalk rivers; the River Kennet and River Frome, show that rivers of similar size and geology do not have the same phosphorus limiting concentration, which indicates that it is not advisable to impose $\mathrm{P}$ concentration targets across river typologies, which is the current approach adopted by the UK's Environment Agency (EA). This study has also shown that the proposed phosphorus concentration target of $60 \mu \mathrm{g} \mathrm{l}^{-1}$ annual average, as set by the EA for chalk rivers, would be too high to reduce excessive periphyton growth in the River Kennet.

This study has shown that a tripling of the ambient $P$ concentration, sustained for a period of nine days, did not increase periphyton accrual rate (Figure 4). Therefore, the excessive biofilm growth and algal dominance of the river ecology cannot be a response to intermittent peaks in SRP concentration. Therefore, the environmental problems in the upper Kennet are not due to regular failures of the Marlborough sewage treatment works. This also explains why the step reduction in SRP concentration from $c a .600$ to $100 \mu \mathrm{g} \mathrm{l}^{-1}$ in $1997 \mathrm{had}$ little effect on the river ecology, as the phosphorus concentration was still in excess for algal growth. However, this study has also shown that further modest reductions in SRP concentration would be likely to reduce the rate of biofilm development, and this could be enough to shift the River Kennet's ecology away from algae dominance, possibly enabling macrophytes to re-establish in the study reach (Hilton et al., 2006). The most effective method of achieving this would be to increase the amount of phosphorus stripping at the Marlborough STW.

\section{Conclusions}

The portable floating flumes developed in this study provided an easy and effective way of producing replicate throughflow mesocosms within any river. Used in conjunction with the phosphorus stripping methodology of Bowes et al., 2007, this provides a powerful tool for determining the threshold $\mathrm{P}$ concentration, below which algal growth will begin to decline. This will enable catchment managers to determine the level of phosphorus reduction measures that would be required for a particular river, before an ecological response is likely to be observed.

This study has demonstrated that further reductions in $\mathrm{P}$ concentration in the upper River Kennet would reduce periphyton growth rates, and this should encourage the ecology to move from being algae dominated towards a macrophyte-dominated system that is desired by land owners and river users. A maximum SRP concentration target of $c a .50 \mu \mathrm{g} \mathrm{l}^{-1}$ during the algae growing season should be enforced, to reduce the risk of an algal-dominated ecosystem. However, it is important to note that nutrient enrichment is only one possible cause of algal domination. Other physical variables, such as river flow, river depth and shading will also have major effects on the balance between algae and macrophytes, and it is vital that catchment managers take these into account when trying to address the problem of excessive algal growth.

\section{References}

Bowes, M.J., Hilton, J., Irons, G.P. and Hornby, D.D. 2005. The relative contribution of sewage and diffuse phosphorus sources in the River Avon catchment, southern England: Implications for nutrient management. Sci. Total Environ., 344, 67-81.

Bowes, M.J., Smith, J.T., Hilton, J., Sturt, M. M. and Armitage, P.D. 2007. Periphyton biomass response to changing phosphorus concentrations in a nutrient-impacted river: A new methodology for $\mathrm{P}$ target setting. Can. J. Fish. Aquatic Sci., 64, 227-238.

Bowes. M.J., Smith. J.T., Jarvie. H.P., Neal. C. and Barden. R. 2009. Changes in point and diffuse source phosphorus inputs to the River Frome (Dorset, UK) from 1966 to 2006. Sci. Total Environ., 407, 1954-1966.

Dawes, E.A. 1972. Quantitative Problems in Biochemistry, Churchill Livingstone, Edinburgh.

EEC 1991. Urban waste water treatment., Vol. Directive 91/271/EEC. European Economic Community, Brussels, Belgium. 
Eisenreich, S.J., Bannerman, R.T. and Armstrong, D.E. 1975. A simplified phosphorus analytical technique. Environ. Lett., 9, 45-53.

Foy, R.H. 2007. Variation in the reactive phosphorus concentrations in rivers of northwest Europe with respect to their potential to cause eutrophication. Soil Use Manage., 23, 195-204.

Harvey, C.J., Peterson, B.J., Bowden, W.B., Hershey, A.E., Miller, M.C., Deegan, L.A. and Finlay, J.C. 1998. Biological responses to fertilization of Oksrukuyik Creek, a tundra stream. J. North Amer. Benthol. Soc., 17, 190-209.

Hilton, J., O'hare, M., Bowes, M.J. and Jones, J.I. 2006. How green is my river? A new paradigm of eutrophication in rivers. Sci.e Total Environ., 365, 66-83.

Jarvie, H.P., Neal, C. and Williams, R.J. 2004. Assessing changes in phosphorus concentrations in relation to instream plant ecology in lowland permeable catchments: Bringing ecosystem functioning into water quality monitoring. Water Air Soil Poll: Focus., 4, 641-655.

Jarvie, H.P., Neal, C., Williams, R.J., Neal, M., Wickham, H.D., Hill, L.K., Wade, A.J., Warwick, A. and White, J. 2002. Phosphorus sources, speciation and dynamics in the lowland eutrophic River Kennet, UK. Sci. Total Environ., 282, 175-203.

Kelly, M.G. and Wilson, S. 2004. Effect of phosphorus stripping on water chemistry and diatom ecology in an eastern lowland river. Water Res., 38, 1559-1567.

Mainstone, C.P. and Par,r W. 2002. Phosphorus in rivers ecology and management. Sci. Total Environ., 282, 25-47.

Marker, A.F.H., Nusch, E.A., Rai, H. and Riemann, B. 1980. The measurement of photosynthetic pigments in freshwaters and standardisation of methods: Conclusions and recommendations. Arch. Hydrobiol. Beih., 14, 91-106.

Marsh, T.J. and Hannaford, J. 2008. UK Hydrometric Register. Hydrological data UK series. Centre for Ecology and Hydrology.

Matlock, M.D., Matlock, M.E., Storm, D.E., Smolen, M.D. and Henley, W.J. 1998. Limiting nutrient determination in lotic ecosystems using a quantitative nutrient enrichment periphytometer. J. Amer. Water Resour. Ass, , 34, 11411147.
Murphy, J. and Riley, J.P. 1962. A modified single solution method for the determination of phosphorus in natural waters. Anal. chemica acta, 12, 31-36.

Neal. C., Jarvie. H.P., Love. A., Neal. M., Wickham. H. and Harman. S. 2008. Water quality along a river continuum subject to point and diffuse sources. J. Hydrol., 350, 154-165.

Nurnberg, G. and Peters, R.H. 1984. Biological availability of soluble reactive phosphorus in anoxic and oxic freshwaters. Can. J. Fish. Aquatic Scie.s, 41, 757-765.

O’Hare, M.T., Clarke, R.T., Bowes, M.J., Cailes, C., Henville, P., Bissett, N., Mcgahey, C. and Neal, M. 2010. Eutrophication impacts on a river macrophyte. Aquatic Bot., 92, 173-178.

Redfield, A.C. 1958. The biological control of chemical factors in the environment. Amer. Sci., 46, 205-221.

Sabater, S., Acuna, V., Giorgi, A., Guerra, E., Munoz, I. and Romani, A.M. 2005. Effects of nutrient inputs in a forested Mediterranean stream under moderate light availability. Archiv Fur Hydrobiologie, 163, 479-496.

Scrimgeour, G.J. and Chambers, P.A. 1997. Development and application of a nutrient-diffusing bioassay for large rivers. Freshwater Biol., 38, 221-231.

Tank, J.L. and Dodds, W.K. 2003. Nutrient limitation of epilithic and epixylic biofilms in ten North American streams. Freshwater Biol., 48, 1031-1049.

Truesdale, V.W. and Smith, C.J. 1975. Formation of molybdosilicic acids from mixed solutions of molybdate and silicate. Analyst, 100, 203-212.

Wade, A.J., Whitehead, P.G., Hornberger, G., Jarvie, H.P. and Flynn, N. 2002. On modelling the impacts of phosphorus stripping at sewage works on in-stream phosphorus and macrophyte/epiphyte dynamics: a case study for the River Kennet. Sci. Total Environ., 282, 395-415.

Wright, J.F., Gunn, R.J.M., Winder, J.M., Wiggers, R., Vowles, K., Clarke, R.T. and Harris, I. 2002. A comparison of the macrophyte cover and macroinvertebrate fauna at three sites on the River Kennet in the mid 1970s and late 1990s. Sci. Total Environ., 282, 121-142. 